\title{
INVESTIGATION OF TWO OUTBREAKS OF GASTROENTERITIS IN TRŽIČ IN SEPTEMBER 2011 PREISKAVA DVEH IZBRUHOV GASTROENTERITISA V TRŽIČU V
SEPTEMBRU 2011
}

\author{
Andreja KRT LAH ${ }^{1}$, Tatjana FRELIH ${ }^{2}$ and Irena GRMEK KOŠNIK ${ }^{3}$ \\ ${ }^{1}$ Health Care Centre Gorenja vas, Trata 7, 4224 Gorenja vas, Slovenia \\ 2 National Institute of Public Health, Trubarjeva 2, 1000 Ljubljana, Slovenia \\ ${ }^{3}$ National Laboratory for Health, Environment and Food, Prvomajska 1, 2000 Maribor, Slovenia
}

\section{ABSTRACT}

Keywords:

outbreak, gastroenteritis, Salmonella Enteritidis, epidemiology
Background. An outbreak of gastroenteritis of etiologically unspecified origin and an outbreak of Salmonellosis occurred simultaneously in September 2011 in Tržič. The purpose of the investigation of both outbreaks was to identify the most probable source and the mode of transmission and to implement preventive measures.

Methods. In two retrospective case-control studies, the association between gastroenteritis of etiologically unspecified origin or Salmonellosis and food from a restaurant or drinking tap water were tested by univariate and multivariate analysis. The subject in the first study was a sick person with salmonellosis, and the subject in the second study was a resident that developed diarrhoea and/ or vomiting. Cases were reported by doctors, and controls were selected from healthy persons who responded to the questionnaire.

Results. A person exposed to food from the restaurant had a 24.8 times higher odds ratio (univariate analysis OR 24.8, 95\% Cl 7.5 to 82.3, p <0.05; multivariate analysis OR 14.7, 95\% Cl $3.5-61.3, \mathrm{p}<0.05$ ) for salmonellosis than non-exposed. A resident exposed to tap water from specific water source had a 3.4 times higher odds ratio (univariate analysis of $\mathrm{OR} 3.4,95 \% \mathrm{Cl} 2.2$ to 5.1 is $\mathrm{p}<0.05$, multivariate analysis of $\mathrm{RO} 2.9,95 \%$ $\mathrm{CI} 1,7$ to $5.3, \mathrm{p}<0.05$ ), for gastroenteritis of unspecific etiology than non-exposed. The dose response relationship was also statistically significant.

Conclusion. Analytical cases - controls studies confirmed a causal relationship between salmonellosis and food from the specific restaurant and the causal relationship between gastroenteritis of etiologically unspecified origin and drinking tap water from specific water source. Salmonella enteritidis may have entered into the restaurant through tap water.

Uvod. Izbruh gastroenteritisa neopredeljene etiologije in izbruh salmoneloze sta bila hkrati v Tržiču septembra 2011. Namen preiskave izbruhov je bil odkriti izvor in poti prenosa okužbe s ciljem, da se sprejmejo ukrepi za prekinitev širjenja.

Metode. $V$ dveh retrospektivnih študijah primerov in kontrol je bila z univariatnimi in multivariatnimi analizami testirana povezava med gastroenteritisom neopredeljene etiologije oziroma salmonelozo in uživanjem hrane $v$ gostilni ali pitjem vodovodne vode. Primer v prvi študiji je bil oboleli s salmonelozo, primer v drugi študiji pa je bil vsak občan z drisko in/ali bruhanjem. Primere obolelih so prijavili zdravniki; kontrole so bile izbrane med zdravimi osebami, ki so vrnile izpolnjeni vprašalnik.

Rezultati. Osebe, izpostavljene hrani $v$ gostilni, so imele 24,8-krat višje obete za obolevanje za salmonelozo kot neizpostavljeni (univariatna analiza RO 24,8; 95 \% IZ 7,5-82,3; $p<0,05$; multivariatna analiza $R O$ 14,7; $95 \%$ IZ 3,5-61,3, p < 0,05). Občani, ki so pili vodo iz določenega vodnega vira, so imeli 3,4-krat višje obete, da so oboleli za gastroenteritisom neopredeljene etiologije kot neizpostavljeni (univariatna analiza RO 3,4; 95 \% IZ je 2,2-5,1; $p<0$,05; multivariatni analizi RO 2,9; 95 \% IZ 1,7-5,3; $p<0,05$ ). Statistično značilna je bila tudi povezava med obolevanjem in količino popite pitne vode.

Zaključki. Z analitičnima študijama primerov in kontrol smo potrdili vzročno povezanost med salmonelozo in prehranjevanjem $v$ določeni gostilni ter povezanost med gastroenteritisom neopredeljene etiologije in pitjem vodovodne vode iz določenega vodnega vira. Mogoč je vnos Salmonelle enteritidis v gostilno prek vodovodne vode. 


\section{INTRODUCTION}

Two simultaneous outbreaks occurred in the area of the municipality of Tržič on the first weekend in September 2011; an outbreak of acute gastroenteritis of etiologically unspecified origin (hereinafter GEC) and an outbreak of enteritis caused by Salmonella Enteritidis infection (hereinafter Salmonellosis). Family outbreak was part of the Salmonellosis outbreak due to home delivered food from the specific restaurant on Sunday, 4 September 2011.

On Saturday, 3 September 2011, a doctor at the health care centre detected an increase in the number of gastroenteritis cases and notified the operator of the public drinking water supply system (hereinafter DWSS) about a suspected water contamination. The epidemiological investigation began on 6 September 2011, as three persons from the municipality were hospitalised in the district hospital with a severe form of intestinal infectious disease (hereinafter IID). In the course of the epidemiological investigation, it became obvious that there were two outbreaks, the outbreak of GEC and of Salmonellosis. The investigation was conducted in cooperation with The Regional Institute of Public Health Kranj, The Health Care Centre Tržič, The National Institute of Public Health, The Regional Unit of the Health Inspectorate, The Regional Unit of the Veterinary Administration and the municipal company Komunala Tržič.

The residents have been supplied with drinking water mainly from public DWSS (81.6\%) and only in a small degree from small village DWSS. The three larger DWSS supplied $74 \%$ of all residents. In the year 2010 and until August 2011, here the source of drinking water was untreated groundwater (1).

The Police Station investigated a spillage of a cesspit substance in the area of the municipality but not in proximity of the water source. The geological structure is otherwise variegated, with alternating Triassic limestone and dolomite and also Permian-Carbonaceous slate and sandstone (2).

According to the data of the Statistical Office of the Republic of Slovenia, on the 30 June 2011 there were 15,207 residents living in 5868 households in the municipality area (3).

The World Health Organisation defines "foodborne / waterborne outbreak" as the occurrence of two or more cases of a similar foodborne / waterborne disease resulting from the ingestion of a common food / water (4).

In the period from 2008 - 2010, from 19 to 55 sporadic cases of GEC and from 0 to 11 Salmonellosis cases were reported. In this period, no outbreaks of GEC or Salmonellosis were reported.

The purpose of the investigation of both outbreaks was to identify the most probable source and the mode of transmission and to implement preventive measures.

\section{METHODS}

\subsection{Identification of cases in the outbreak}

\subsubsection{Preliminary telephone survey}

On 6 September 2011, we conducted telephone interviews with 50 randomly selected households in the area of the municipality.

\subsubsection{Epidemiologic surveillance}

According to the Communicable Diseases Act, all doctors have to report a diagnosed IID to the regional epidemiologist. All doctors were asked for consistent and on time notification of IID and shipment of samples. For the reported cases of IID, a descriptive epidemiologic analysis was conducted.

A case was defined as a resident who sought medical help from 30 August to 20 September 2011 because of IID as well as non-residents who had consumed food in a specific restaurant or had drunk tap water from the water distribution system in the area of the municipality.

\subsubsection{Microbiological investigation}

Stool samples were cultured for Shigella, Campylobacter, Salmonella, E. coli, Yersinia. The samples were also tested for norovirus, adenovirus and rotavirus as well as for parasites. The samples were primarily planted on the selective/differential medium Xylose Lysine Desoxycholate agar (BBL) and on the selective enrichment medium Rappaport Vassiliadis Soya buion (Oxoid). After the isolation of pure bacteria culture, the subspecies Salmonella enterica subspec. was defined with biochemical tests. The bacteria serotype Salmonella Enteritidis was determined by agglutination. In order to determine the relatedness of the isolated bacteria Salmonella Enteritidis, the isolates of 15 sick persons with a severe clinical picture were sent for typing by the method PFGE (Pulsed-field gel electrophoresis according to Struelens and with Xba I as used restriction enzyme). The results of the PFGE method were statistically processed in the program Gel Compar and the relatedness was computed (Dice coefficient, optimisation $1 \%$, tolerance $1 \%$ ).

\subsection{Environmental investigation}

\subsubsection{Drinking water samples}

The criteria for parameter evaluation have been derived from the Rules on drinking water (indicator presence of E. Coli, coliform bacteria and enterococcus) and directed to Salmonella spec. The drinking water samples were taken on 5 September 2011 (so-called MSD quick test by the IDEXX COLILERT $®-18$ test method), 7 September 2011, 8 September 2011 and 9 September 2011 (membrane filtration by the method of SIST EN ISO 9308-1:2001/AC: 2009, and SIST EN ISO 6222:1999 for the presence of Salmonella spp. By the method of ISO 19250). 


\subsubsection{Food}

On-site inspection was conducted in the restaurant and at local food producers. Food samples had not been taken. According to the Rules on health requirements for persons in contact with food at food processing and trade, all food handlers in the specific restaurant were required to undergo medical examination.

\subsection{Analytical studies}

\subsubsection{Case-control study number $1(\mathrm{n}=113$, Salmonellosis cases $=21$, controls $=92$ )}

The aim of the study was to test the hypothesis that the risk factor for the Salmonellosis was exposure to food from the specific restaurant or drinking water from specific DWSS.

A case meant a resident or non-resident who had consumed food in a specific restaurant or had drunk drinking water from a specific DWSS with laboratory-confirmed Salmonellosis from 30 August to 20 September 2011.

On 9 September 2011, a questionnaire was sent by nonaddressed mail to approximately 6000 households in the municipality with the aim of acquiring data about the number of the persons affected in outbreak and about common food and waterborne exposure. With this questionnaire, data on gender, age, symptoms of gastroenteritis (temperature above $37.5{ }^{\circ} \mathrm{C}$, abdominal pain, nausea, vomiting and diarrhoea), doctor's visits, providing of stool samples for testing, possible hospitalisation, other sick persons in the same household, food exposure outside the home and home food delivery, including eating in a specific restaurant, buying habits and the kind of food ingested during the time of the outbreak, travelling outside the community and having pets in the household were gathered. For controls in the study, 92 persons were randomly selected from the group of (442) persons that had returned the questionnaire and had not indicated gastroenteritis symptoms (healthy controls). The data have been statistically processed and analysed with the program Epiinfo 2000.

The null-hypothesis that the Salmonellosis was not connected with exposure to the food from the specific restaurant and /or to drinking water from specific DWSS was tested with univariate analysis. The statistical test hiquadrat was used for the calculation of the $p$-value. The relatedness of gender, age, eating in the restaurant and consumption of drinking water to the emergence of infection was also tested by a multivariate analysis (logistic regression).

\subsubsection{Case-control study number $2(n=442$, GEC cases $=151$, controls $=291$ )}

The aim of the study was to test the hypothesis that the risk factor for the GEC was exposure to food from the specific restaurant or drinking water from specific DWSS. A case was a person that replied to the questionnaire and had diarrhoea and/or vomiting in the period from $30 \mathrm{Au}$ gust to 20 September 2011. On the base of returned questionnaires (already described in point Methods 2.3.1), 151 persons met the criteria for the case definition. As the control group, 291 persons that had not indicated any symptoms were classified. The data was statistically processed in the same way as described in point Method 2.3.1.

\section{RESULTS}

\subsection{Identification of cases in the outbreak}

\subsubsection{Preliminary telephone survey}

In the preliminary phone survey, $20 \%$ of the households reported gastroenteritis in at least one family member.

\subsubsection{Epidemiologic surveillance}

From 30 August 2011 to 20 September 2011, there were 21 reported cases of Salmonellosis (ICD A02.0) and 69 cases of the GEC (ICD A09.0). The cases presented with diarrhoea, bloody diarrhoea, abdominal pain and general weakness and only a smaller part of them also reported vomiting and temperature above $37.5^{\circ} \mathrm{C}$. The age structure of the cases is presented in Table 1, the date of disease onset in Figure 1.

\subsubsection{Human samples}

Stool samples were obtained from 22 cases. For 12, stool sample analysis for pathogenic intestinal bacteria (Shigella, Campylobacter, Salmonella, E. coli, Yersinia), viruses (noroviruses, adenoviruses and rotaviruses) and parasites was performed; for the remaining only the presence of the bacteria Salmonella Enteritidis was analysed.

Table 1. Reported cases of IID from 30 August to 20 September 2011.

\begin{tabular}{|c|c|c|c|c|c|c|}
\hline $\begin{array}{l}\text { Age distribution } \\
\text { (years) }\end{array}$ & $\begin{array}{l}\text { Reported } \\
\text { incidence } \\
/ 10,000 \\
\text { population }\end{array}$ & $\begin{array}{l}\text { Total number of } \\
\text { reported IID }\end{array}$ & $\begin{array}{l}\text { Number of } \\
\text { reported GEC }\end{array}$ & $\begin{array}{l}\text { Number of } \\
\text { hospitalised } \\
\text { GEC cases }\end{array}$ & $\begin{array}{l}\text { Number of lab. } \\
\text { confirmed cases } \\
\text { (Salmonella } \\
\text { Enteritidis) }\end{array}$ & $\begin{array}{c}\text { Number of } \\
\text { hospitalised } \\
\text { salmonellosis } \\
\text { cases }\end{array}$ \\
\hline $0-14$ & 62.40 & 13 & 5 & 0 & 8 & 5 \\
\hline $15-64$ & 64.25 & 68 & 56 & 0 & 12 & 2 \\
\hline $65+$ & 35.44 & 9 & 8 & 0 & 1 & 1 \\
\hline All & 59.18 & 90 & 69 & 0 & 21 & 8 \\
\hline
\end{tabular}




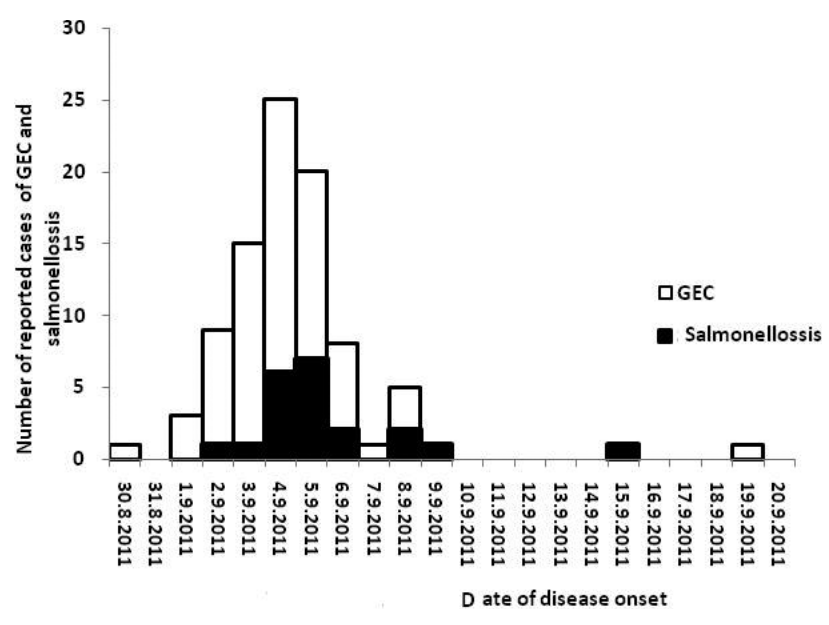

Figure 1. Date of GEC and Salmonellosis onset among reported cases IID $(n=90)$.

In 21 stool samples, the bacteria Salmonella Enteritidis was confirmed. A molecular typing (PFGE) of the 15 sent isolates of the bacteria Salmonella Enteritidis showed 99.99\% relatedness and confirmed that all isolates belong to the same epidemical strain, which is otherwise the second most common to appear in Slovenia.

The results of all other microbiological tests were negative.

\subsection{Environmental investigation}

\subsubsection{Drinking water samples}

Water samples were taken in the period when the number of cases was declining. Samples of drinking water from a specific DWSS, obtained on 5 September 2011, were in 2 cases non-conforming due to the presence of coliform bacteria, in three samples, obtained on 7 September 2011 from the DWSS in households of the diseased, due to the presence of $\mathrm{E}$. coli and coliform bacteria and in one sample due to the presence of E. coli, coliform bacteria and enterococci. The sample obtained on 8 September 2011 was a non-conforming sample due to the presence of $E$. coli and coliform bacteria and enlarged count of colonies at $36{ }^{\circ} \mathrm{C}$. Both samples obtained on 9 September 2011 were conforming. Salmonella spp. was not proven in any of the obtained samples.

\subsubsection{Food}

The extraordinary on-the-spot inspection on 7 September 2011 revealed a number of non-conformities in a specific restaurant. The restaurant was very popular in the settlement; they ran a home delivery up to $15 \mathrm{~km}$. The kitchen was planned for far lower capacities compared to the actual number of daily prepared meals. The hygienic situation in the kitchen was bad, the rooms and equipment poorly maintained and the documentation incomplete. Clean and unclean pathways were crossed; temperatures were not suitable. One of the food handlers reported gastroenteritis symptoms but had not ceased to work. In him and another employee, the bacteria Salmonella Enteritidis was confirmed to be $99.99 \%$ related to the isolates of the other cases in the outbreaks. Drinking water from a specific DWSS, which was analysed in both analytical studies, had been used for the food preparation, as the restaurant was supplied with drinking water from this specific DWSS. Food (two plates with grilled minced meat, fried turkey steaks and steaks in sauce, dumplings, fried potatoes and grilled vegetablest for a family picnic, where 12 of 16 persons got Salmonellosis, was home delivered by this specific restaurant.-

There were no non-conformities with the local food producers.

\subsection{Analytical studies}

\subsubsection{Case-control study number 1 ( $n=113$, Salmonellosis cases $=21$, controls $=92$ )}

Case definition criteria corresponded to 21 of the Salmonellosis cases reported by the doctors. All cases were interviewed by the regional epidemiologist with the same questionnaire as was distributed to the households of the municipality. The onset of Salmonellosis is presented in Figure 2.

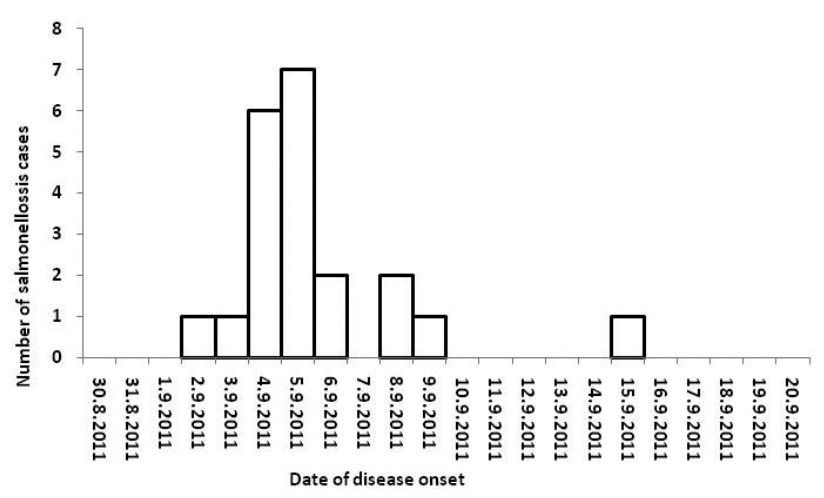

Figure 2. Date of Salmonellosis onset $(\mathrm{N}=21)$.

The persons exposed to the food in the restaurant had a 24.8 times greater probability of Salmonellosis than un-

Table 2. Univariate analysis for exposure to food from restaurant.

\begin{tabular}{lcccc}
\hline $\begin{array}{l}\text { Exposure to food from } \\
\text { specific restaurant }\end{array}$ & $\begin{array}{c}\text { Salmonella Enteritidis } \\
\text { cases }\end{array}$ & Controls & $\begin{array}{c}\text { Odds ratio (OR) with } \\
\text { confidence interval }(\mathrm{Cl})\end{array}$ & $\mathrm{P}$ - value \\
\hline YES $(+)$ & 14 & 8 & $95 \% \mathrm{Cl} 7.5-82.3$ & $\mathrm{P}<0.05$ \\
NO $(-)$ & 6 & 85 & Ref & \\
\hline
\end{tabular}


exposed persons (univariate analysis OR 24.8; 95\% Cl 7.5 - 82,3; $p<0.05$; multivariate analysis OR 14.7; $95 \% \mathrm{Cl} 3.5$ $61.3, p<0.05$ ). The difference is statistically significant ( $p$ $<0.05$ ). The results are presented in Table 2 . By multivariate analysis (logistic regression), the persons exposed to the food in the restaurant also had a 14.7 times greater probability (OR 14.7; 95\% IZ $3.5-61.3$; p < 0.05) of getting Salmonellosis than unexposed persons.

The persons exposed to the specific DWSS had the same probability of Salmonellosis as unexposed persons (OR 1.0; $95 \% \mathrm{Cl} 0.4-2.6)$.

\subsubsection{Case-control study number 2}

$$
(n=442, \text { GEC cases }=151 \text {, controls }=291)
$$

The questionnaire was returned by post, fax or into the mailbox at the community health centre by 442 persons. The onset of disease with GEC is presented in Figure 3.

The persons exposed to drinking water from a specific DWSS, had 3.4 greater probability of getting GEC than persons exposed to drinking water from other DWSS (univariate analysis $\mathrm{OR} 3.4 ; 95 \% \mathrm{Cl} 2.2$ - 5.1) This difference is statistically significant $(p<0.05)$. The results are presented in Table 3. Those exposed to drinking water from a specific DWSS also had a 2.9 times greater probability (OR 2.9; 95\% Cl $1.7-5.3$ ) to get GEC according to the multivariate analysis (logistic regression). The difference is statistically significant $(p<0.05)$.

Table 3. Univariate analysis for exposure to tap water from the specific DWSS.

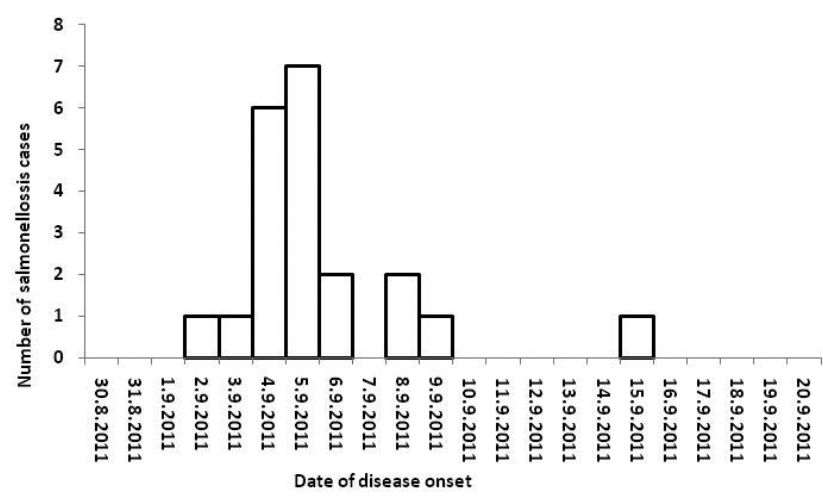

Figure 3. Date of GEC onset among the population according to the data from questionnaire $(\mathrm{N}=151)$.

\subsection{Implemented preventive public health measures}

On 6 September 2013, the operator of the public DWSS advised its users to boil their tap water. An inspection of the DWSS was conducted with the control of possible pressure drops in the network and of the defect log for the last two weeks. After water sampling and user notification, the cleaning and washing out of the complete DWSS was executed, together with its disinfection by chlorine substances.

The measure of tap water boiling was cancelled on 10 September 2011.

\begin{tabular}{lcccc}
\hline $\begin{array}{l}\text { Exposure to tap water } \\
\text { from specific DWSS }\end{array}$ & GEC cases & Controls & $\begin{array}{c}\text { Odds ratio (OR) with } \\
\text { confidence interval(Cl) }\end{array}$ & $\mathrm{p}-$ value \\
\hline YES $(+)$ & 101 & 109 & $\begin{array}{c}3,4 \\
95 \% \mathrm{IZ} / \mathrm{Cl} 2.2-5.1\end{array}$ & $\mathrm{p}<0.05$ \\
NO $(-)$ & 50 & 182 & Ref & \\
\hline
\end{tabular}

The stratified analysis (dose response relationship) indicates a statistically significant relationship between illness and the quantity of ingested tap water of 0 to 1 litre or more per day $\left(\mathrm{x}^{2}{ }_{\text {trend }}=6.01, \mathrm{p}<0.01\right)$ (Table 4). The risk of illness increased with the amount of daily consumed tap water.
In the restaurant, a general cleaning and education about the HACCP system took place; six employees underwent medical examination with counselling. One person was temporarily prohibited from work. The HACCP system was upgraded. The owner promised to try to establish a new kitchen due to the large number of prepared meals.

Table 4. Stratified analysis of multiple levels of exposure due to daily amount of ingested tap water.

\begin{tabular}{|c|c|c|c|c|}
\hline $\begin{array}{l}\text { Daily amount of } \\
\text { ingested tap water }\end{array}$ & $\begin{array}{c}\text { Cases with diarrhoea } \\
\text { and/or vomit }\end{array}$ & Controls & $\begin{array}{l}\text { Odds ratio (OR) with } \\
\text { confidence interval(CI) }\end{array}$ & $p$ - value \\
\hline$>=1$ litre & 103 & 161 & $\begin{array}{c}2.6 \\
95 \% \mathrm{Cl} 0.5-12.3\end{array}$ & $p=0.24$ \\
\hline $0,5 \mathrm{l}$ & 38 & 80 & $\begin{array}{c}1.9 \\
95 \% \text { CI 0.4-9.3 } 4\end{array}$ & $p=0.43$ \\
\hline $0,2 \mathrm{l}$ & 5 & 22 & $\begin{array}{c}0.9 \\
95 \% \text { CI } 0.1-5.7\end{array}$ & $p=0.91$ \\
\hline Did not drink tap water & 2 & 8 & Ref. & \\
\hline
\end{tabular}

Persons exposed to food from the specific restaurant had the same probability of getting the GEC as non-exposed (OR 1.0; 95\% Cl $0.4-2.6 \mathrm{p}>0.05$ ). 


\section{DISCUSSION}

The outbreaks investigation type has its limitations when compared with planned scientific studies. Often the outbreak is detected with a delay, the data gathering is influenced by the recall bias, time pressure is always present in the processing of the outbreak, quick action is necessary according to the information and facts available and decisions for compromise solutions need to be made. Additionally, sometimes it is not possible to acquire adequate environment samples due to the delay of processing.

The doctor at the health centre, who on 3 September 2011 suspected the outbreak of IID, should have, according to the Communicable Diseases Act, informed the regional epidemiologist; instead he decided to inform the operator of the DWSS, as he suspected water pollution. The DWSS operator should immediately have informed the regional epidemiologist and decided on water boiling in the case of suspicion of water pollution according to the Rules on drinking water; instead of that, they informed the Department for Drinking Water after a two day delay and introduced water boiling on 6 September 2014.

The epidemiological investigation of the outbreak started on 6 September 2011, after 3 persons with a serious form of Salmonellosis had been hospitalised and it was not yet clear that there were two outbreaks. The determination of the outbreak was immediately followed by the outbreak investigation, with activation of different services: the Institute of Regional Public Health Kranj, National Institute of Public Health, inspection bodies and the DWSS operator. No earlier than in the course of the epidemiological investigation, it became obvious that there were two outbreaks, the outbreak of GEC and of Salmonellosis.

During the time of the outbreak from 30 August 2011 to 20 September 2011, 90 persons had sought medical help because of intestinal infectious disease due to diarrhoea, bloody diarrhoea, abdominal pain, general weakness and vomiting. Doctors reported 21 cases of Salmonellosis (ICD A02.0) and 69 cases of GEC (ICD A09.0); a total of 90 cases. The epidiagram showed a point source of infection and the peak of GEC outbreak on 4 September 2011 and the peak of Salmonellosis outbreak on 5 September 2011. The attendees of the family picnic were also part of Salmonellosis outbreak, due to home delivery food from the specific restaurant on 4 September 2011.

From the stool of 21 cases, the bacteria Salmonella Enteritidis was isolated; the isolates were related considering the molecular typing (PFGE) in $99.99 \%$ and belonged to the same epidemical strain, which is otherwise the second most common to appear in Slovenia. The presence of other IID agents was not detected in any of the stool samples.

Residents were supplied with drinking water mainly from public DWSS with underground water, where disinfection and other preliminary water treatment had not been done in 2010 and up until August 2011. Water samples were taken at the time when the number of cases was declining. In samples of drinking water from households of the cases, obtained from 5 to 9 September 2011, indicative parameters for faecal contamination of drinking water were present, but the bacteria Salmonella spec. was been isolated.

The on-site inspection in the specific popular local restaurant, where home deliveries were also made, discovered a range of non-conformities; in two employees, the bacteria Salmonella Enteritidis was isolated; according to the molecular typing (PFGE), the isolates were related in 99.99\% to those in the diseased persons. The restaurant had been supplied with drinking water from the specific DWSS, which was also the risk factor for the GEC.

According to EFSA directives, in the absence of laboratory confirmation of the same disease agent in infected persons in the outbreak and in the food, respectively drinking water, the analytical epidemiologic investigation provides equal proof, where either the cohort study or case control study proves a statistically significant association between the ingestion of a common food and the people who became ill in the outbreak (5).

With the aim of gathering additional data to clear up what was happening and why, we wanted to obtain data for analytical epidemiologic studies based on questionnaires, which on 9 September 2011 were sent in single copy by non-addressed mail to approximately 6000 households. 442 questionnaires were returned; 151 of them classified among the diseased with GEC. The sampling would be more adequate if a representative resident sample had been selected. For this reason and low response, we decided in favour of case control studies.

The persons exposed to the food in the restaurant had a 24.8 times greater probability for Salmonellosis (univariate analysis OR 24.8; 95\% Cl 7.5 - 82.3; p < 0.05; respectively 14.7 times (multivariate analysis OR $14.795 \% \mathrm{Cl}$ 3.5-61.3, $\mathrm{p}<0.05$ ) greater probability for Salmonellosis than unexposed persons.

In the period from 1996 - 2005, Salmonella spp. was the second largest cause of gastroenteritis in Slovenia, with an average yearly incidence of 103.3 / 100,000 inhabitants and was also a common source of outbreaks. In $84.4 \%$, isolates of Salmonella Enteritidis were found (6). The epidemiologic reservoir of infection is poultry, pigs, dogs, cats, birds and other wild animals. The clinical picture includes nausea, vomiting, diarrhoea, temperature and abdominal spastic pains. The incubation period is from 12 to 24 hours ( 7 to 72 hours). The disease lasts for 3 to 5 days. A severe course of disease emerges with small children, elderly persons, chronic patients and patients with defective immunity. The peak of infection is in summer (7).

The analysis of waterborne outbreaks in Slovenia in the period from 1981 - 2004 showed that the agents were determined only for half of the outbreaks: most often Shigella sonnei $(22 \mathrm{x})$, to a lesser extent also noroviruses, hepatitis A virus, Shigella flexneri, E. coli, Campylobacter, Streptococcus faecalis, rotaviruses, adenoviruses, astroviruses, Entamoeba histolytica and Lamblia intestinalis 
(8). The bacteria Salmonella spec. has never been found as a source of waterborne outbreaks.

Food is the primary, most important and most common method for infection with the bacteria Salmonella Enteritidis (7), so we believed that food was the main source of infection in patients with Salmonellosis. But for six people infected in the outbreak, there was no clear epidemiologic connection with the specific restaurant, although their bacteria isolates were $99.99 \%$ related to the people who were infected via the ingestion of food from the restaurant. However, the restaurant had also been supplied with drinking water from a specific DWSS that was the subject of the epidemiologic investigation and the risk factor for GEC.

According to the literature, water contaminated with salmonellas can be the source of bacteria transfer on food (9). The presence of salmonellas in drinking and bathing water is the result of surface faecal pollution of the water from sewage, trickling water from agricultural land, cesspit leaking and excrement of wild animals and birds (7). The Salmonellas can survive in water for longer periods and can also breed in heavily polluted water and during warmer months of the year. There is evidence of the presence of Salmonella in the biofilms of the water supply systems. In the USA, in the area of evidence of a high degree of infections by salmonellosis, research of surface water on its presence was conducted from April 2005 to April 2006. The bacteria Salmonella spp. was determined in $79.2 \%$ of water samples. The highest monthly occurrence rate and the highest number of different salmonella serotypes in water were found in August, and in general, the concentrations were significantly higher in the summer months (10).

In the literature we may observe that the bacteria Salmonella spp. is a potentially possible but rare cause of waterborne outbreaks. In the outbreak of Salmonella Enteritidis in Colorado, 111 persons got sick. Salmonella Enteritidis was found in untreated groundwater, which was the water source for the town water supply system. Obviously, contamination occurred due to adverse conditions, as the PFGE analysis confirmed the identity of the serotypes of Salmonella Enteritidis in groundwater, in the people affected with disease and in local birds and game (11). The hydric outbreak with the bacteria Salmonella enterica serotype 4,5,12:i:- (serotype which is similar in antigens to Salmonella Typhimurium) was the consequence of infection of a private water supply system (12). The pollution of water tanks on the site by frog and/or mouse excrement led to the outbreak with the bacteria Salmonella Saintpaul, with 28 cases of gastroenteritis among more than 200 workers (13).

We confirmed the causal connection between the gastroenteritis and drinking water from a specific water source by the epidemiologic investigation and two analytical case and control studies and also confirmed the connectedness between the Salmonella enteritis and food ingestion in a specific restaurant. In the Salmonellosis outbreak, food ingestion in a specific local restaurant was a risk factor, where many irregularities in connection with the HACCP system were found and two of the employees also had the bacteria Salmonella Enteritidis present in their stools.

Additionally, this restaurant was supplied with drinking water from the specific DWSS. According to the fact that both outbreaks took place concurrently, in the same geographical area, it can be concluded that in the restaurant the intake of Salmonella enteritidis also occurred through tap water from the DWSS and due to non-compliance with the HACCP recommendations, salmonellosis occurred in people who had consumed food from this restaurant. Both outbreaks, the outbreak of non-specific gastroenteritis and the outbreak of Salmonellosis, are probably the consequence of faecal contamination of the specific DWSS.

\section{CONCLUSION}

We confirmed the casual connection between the gastroenteritis and drinking water from a specific DWSS by the epidemiologic investigation and two analytical case and control studies and also confirmed the connection between the Salmonella enteritis and food ingestion in the specific restaurant. According to the fact that both outbreaks took place concurrently, in the same geographical area, it can be concluded that in the restaurant the intake of Salmonella enteritidis also occurred through drinking water from the DWSS, and due to non-compliance with the HACCP recommendations, salmonellosis occurred in people who had consumed food from this restaurant. The source of infection was probably the consequence of faecal contamination of the specific water source.

The most important aims of processing outbreaks are public health measures for the protection of public health and an outbreak analysis to prevent outbreaks in the future.

According to the Rules on drinking water, the operator of the DWSS can decide on his/her own when water boiling will be introduced; perhaps in future this competence could be assigned to professional services.

Based on the approach to this outbreak, we can conclude that timely communication between the medical service, epidemiological service and DWSS operators is pivotal.

The kitchen in the restaurant was planned for preparation of a much lesser number of meals than were actually prepared and had many deficiencies according to the HACCP system. In planning ordinary inspections, the inspection services should also consider the number of prepared meals, i.e. volume of sales.

\section{ACKNOWLEDGEMENT}

For their help in the processing of the outbreak, we thank our colleagues at the Department for Communicable Diseases: Monika Ribnikar, Urška Milič, Nataša Selan and Veronika Meglič. 


\section{CONFLICT OF INTEREST}

The authors declare that no conflict of interest exist.

\section{FUNDING}

None.

\section{ETHICAL APPROVAL}

Not required.

\section{REFERENCES}

1. Komunala Tržič. Letno poročilo o oskrbi s pitno vodo. Available September 29, 2011 from: http: //www.komunala-trzic.si.

2. Kramar R. Geološka sestava tal v občini Tržič. Available December 1, 2011 from: http://geo2.ff.uni-lj.si/pisnadela/pdfs/dipl_200707_romana_kramar.pdf.

3. Statistični urad RS. Prebivalstvo Slovenije 1. julij 2011. Available September 20, 2011 from: http://www.stat.si/.
4. WHO. Foodborne disease outbreak: guidelines for investigation and control. Available December 12, 2011 from: http://whqlibdoc.who. int/publications/2008/9789241547222_eng.pdf.

5. EFSA. Guidance document from the Task Force on Zoonoses Data. Collection on manual for reporting of food-borne outbreaks in the framework of Directive 2003/99/EC. Available September 6, 2011 from: http://www.efsa.europa.eu/en/scdocs/doc/257r.pdf.

6. Krt Lah A. Analiza spremljanja črevesnih nalezljivih obolenj v Sloveniji v letih 1995-2006: specialistična naloga. Ljubljana: Medicinska fakulteta, 2008.

7. Waterborne pathogens. Available September 11, 2011 from:: http:// www. waterbornepathogens.org/index. php?option=com.

8. Hočevar A, Hojs A, Vračko P. Hidrični izbruhi v Sloveniji. Available August 26, 2011 from: http://www.sdzv-drustvo.si/si/vodni_dnevi/2005/ referati/10-Hocevar-Grum.pdf

9. Levantesi C, Bonndonna L, Briancesco R. Salmonella in surface and drinking water: occurrence and water-mediated transmission. Food Res Int 1993; 45: 587-602.

10. Halley JB, Cole DJ, Lipp EK. Distribution, diversity and seasonality of waterborne Salmonellae in a rural watershed. Appl Environ Microbiol 2009; 75: 1248-55.

11. Berg R. The Alamosa Salmonella outbreak: a gumshoe investigaion. J Environ Health 2008; 71: 54-8.

12. Kozlica J, Claudet AL, Solomon D, Dunn JR, Carpenter LR. Waterborne outbreak of Salmonella. Foodborne Pathog Dis 2010; 7: 1431-3.

13. Taylor R, Sloan D, Cooper T, Morton B, Hunter I. A waterborne outbreak of Salmonella Saintpaul. Commun Dis Intell 2000; 24: 336-40. 